\title{
A Preliminary Study on the Effects of Organic Pollution of Banners Corner Cave, Virginia
}

\author{
By John R. Holsinge R ${ }^{1}$ )
}

With 2 figures in the text

Banners Corner Cave ${ }^{2}$ ) was explored by the writer and a small party of speleologists on November 23, 1961. The cave is located in the village of Banners Corner, Russell County, Virginia, and is well known to residents of that area.

Initial exploration resulted in the discovery of an exceedingly large population (by hypogean standards) of planarians, Phagocata subterranea $\mathrm{Hyman}^{3}$ ); and isopods, Asellus recurvatus Steeves. Both species were observed in a number of small pools within the first 150 meters of the cave. A second significant observation was that the pools occupied by these animals appeared to be contaminated by a brown, sludge-like material. This material was tentatively identified as sewage and the identification was later verified when examination of the terrain above the cave revealed a number of houses with septic tanks located directly over the cave passages below.

Biological exploration of other Appalachian caves previous to this time had revealed a number of populations of troglobitic isopods (Asellus recurvatus, A pricei Levi, and A. richardsonae Hay) and troglobitic planarians (Sphalloplana virginiana Hyman), but none of these populations approached the size of those in Banners Corner Cave. It appeared probable that a trophic relationship existed between the influx of sewage and the larger number of aquatic cavernicoles which inhabited the pools. Although situations comparable to the one in Banners Corner Cave probably exist elsewhere, none appear to have reported. While it has been established that the size of cavernicole populations in the aphotic zone of caves is often influenced to a large extent by the amount of available food (Husson, 1962; Poulson, 1964), few quantitative or correlative data are available.

1) Dept. of Zoology and Institute of Speleology, University of Kentucky, Lexington, U.S.A.

2) This cave is also known as Rock House Cave and Big Spring Cave.

3) Determination by L. H. Hyman. There was only one sexually mature worm in the material identified by Dr. Hyman, and a confirmation of this determination based on additional specimens would be desirable. 
Acknowledgements: The writer is indebted to a number of persons who assisted with this study. Robert A. Kuehne analyzed water samples and Wendall E. Allen prepared culture media for bacteriological tests. John E. Cooper, Russell M. Norton, and Stewart B. Peck assisted with the field work, and Sylvia S. Talmage, James M. Edney, and Willard Jinks aided in the identification of microorganisms.

\section{Methods and Materials}

Six visits, including the one already mentioned, were made to Banners Corner Cave between November 23, 1961, and February 29, 1964. The first five trips consisted chiefly of recording a number of general observations. On the sixth trip (February, 1964) water samples were collected and analyzed, population counts were made, and a preliminary microbiological study was initiated.

Free oxygen concentration was determined by the Alsterberg (azide) modification of the Winkler method; chloride content was determined by the silver nitrate titration method; and total alkalinity was determined by the methyl orange indicator method. Hydrogen ion concentration was obtained with the use of $\mathrm{pH}$ meter.

Population densities (for isopods) were obtained by counting all individuals in a given pool and dividing this number by the number of square meters in that particular pool. A few animals escaped being counted because of their concealment under rocks, but since all counts were made in the same manner, a relationship in the number of animals between different pools was obtained.

The presence of coliform bacteria was detected in accordance with the Standard Presumptive Test described by the American Public Health Association (1960). The presence of other types of bacteria was detected by incubating tubes of nutrient broth (1\% dextrose) which had been inoculated with pool water and associated sediments.

On March 1, 1964, tests similar to those discussed above were made on a pool in Chadwell's Cave, Claiborne County, Tennessee. This cave also contains populations of isopods (A. recurvatus) and planarians (Sphalloplana sp.), but both forms occur there in much less abundance than in Banners Corner. The water in Chadwell's Cave is not visibly polluted, and in view of the fact that this cave contains the same isopod species as Banners Corner Cave it was felt that the data obtained from there would be useful for comparative purposes. 


\section{Physical Description}

Banners Corner Cave is excavated in the Maryville limestone of Cambrian age, and its development appears to have been primarily joint controlled under essentially phreatic conditions. The cave is situated in strata which strike $\mathrm{N} 70^{\circ} \mathrm{E}$ and dip to the southwest at approximately 23 degrees. More than 300 meters of passage have been explored and although much more is rumored to exist, the sketch map (Fig. 1) represents the limits of the cave presently known to the writer.

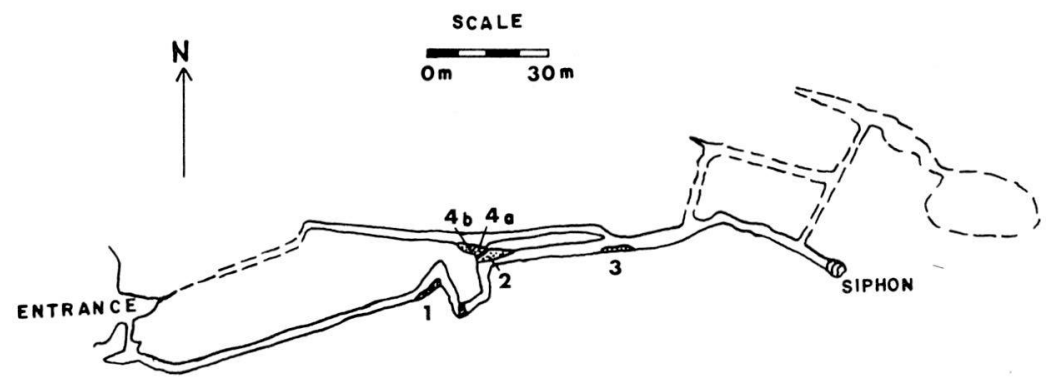

Fig 1. Sketch map of Banners Corner Cave from a compass and pace survey by J. R. Holsinger and J. E. Cooper, November 30, 1961. Pools are indicated by numbers. Broken lines indicate conjectured passage.

A medium-sized surface stream sinks into the ground about 70 meters in front of the entrance but does not appear in the cave until the siphon (see Fig. 1) is reached at the end of the main passage. Four pools (indicated in Fig. 1) are found between the entrance and the siphon, but their source of water is from seepage rather than from a stream. Since these four pools were the center of attention during this study they will be described in some detail.

Pool 1 is a shallow (5.0-7.5 centimeters deep) rock basin situated in a slight recess off the main passage and is about 1.3 meters above the level of the passage. Pool 1, as well as Pool 4, is located on the first or upper level of the cave. The pool measures 1 meter by 2 meters and contains a mud bottom at one end and a rock bottom at the other. It is fed by a seep from a ceiling crevice which sends water downward in the form of a film extending about 3 meters along a flowstone wall adjacent to the basin. The mud bottom of this pool is actually a combination of sewage particles and silt.

Pool 2 is somewhat larger than Pool 1 and measures 7 meters in length but varies in width from 1 meter at one end to 2.5 centimeters at the other. It varies in depth from 15 centimeters in the center to 
2.5 centimeters along the edges. The source of water for Pool 2 is a combination of a slow spill-over from Pool 4 a (located about 3 meters above it at the wide end) and a film of water which is fed from a separate source on the upper level. The bottom of this pool is covered, but not uniformly, by sewage particles and inorganic silt. The substrate below the sediments is mostly small rocks and assorted gravels.

Pool 3 is a shallow basin in the clay floor along one side of the cave passage. Its level of water varies in depth with seasonal runoff. No sewage has been noted in this pool although it is partially filled with vegetable debris which accumulates there after flooding. Its source of water during normal conditions is a slow seep from a wall crevice.

Pool 4 is divided into two smaller pools by a series of small rimstone dams which incompletely separate the two bodies of water. The upper portion of the pool (designated 4b) is the larger of the two divisions (1 by 3 meters) and appears to be fed by uncontaminated water from a wall seep. The lower portion (designated 4 a) measures 125 centimeters in diameter and receives as its main source of water a polluted seep from the adjacent passage wall. To a lesser extent Pool $4 \mathrm{a}$ is fed by a slow spill-over from Pool $4 \mathrm{~b}$. Pool $4 \mathrm{a}$ is about 7.5 centimeters deep at its center and its bottom is covered by an accumulation of silt and sewage particles. Pool $4 \mathrm{~b}$ is comparatively free of sewage (although some apparently gets into its lower end through back-up

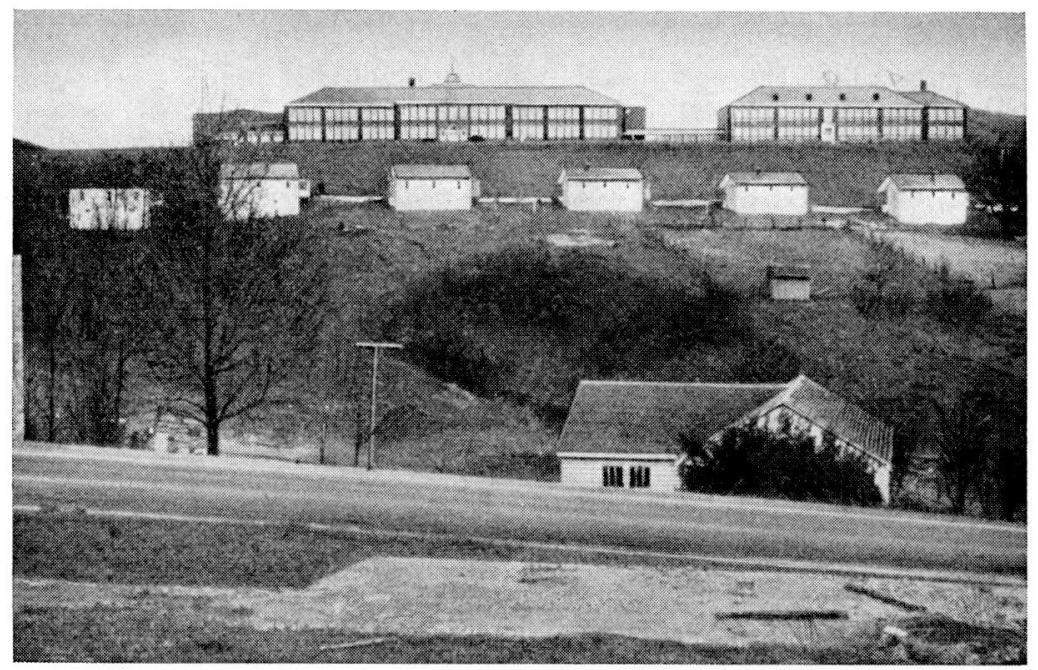

Fig. 2. Entrance to Banners Corner Cave, Russell County, Virginia. The main cave passage extends to a point somewhere beneath the school building shown in the background. (Photograph by the author.) 
from 4a), and its bottom is composed largely of silt and small particles of vegetable material.

A general idea of the surface features above Banners Corner Cave can be obtained by reference to Figure 2. Two school buildings were constructed on the hill above the cave in 1949, and in 1950 (or shortly thereafter) nine houses were built less than 300 meters in front of the school. Personal communication with local residents indicates that each of the nine houses is provided with a septic tank and that two additional tanks are utilized by the school. At least three and possibly four of the septic tanks are located in such a position on the hill that the effluent from their overflow pipes can pass without difficulty downward along bedding planes to the point of intersection of the cave passages below. The estimated vertical distance from the tanks to the cave passages is between 13 and 16 meters.

The exact composition of the sewage effluent is not known except that it appears as a brown watery film on the cave walls, and where it accumulates in the pools it forms a brown residue on the bottom. The contaminated pools contain a great deal of colloidal material which remains suspended in the water as small, amorphous clusters. In a properly functioning septic tank most of the heavier material accumulates on the bottom as sludge and the lighter colloidal particles pass to the top and are emitted through the overflow pipe into the surrounding ground. It is apparently overflow material which makes up the largest percentage of the sewage that seeps into the cave pools.

Microscopic examination of the residual sediments from the bottom of Pools 2 and 4 a indicate that its composition is about 75 per cent inorganic silt and clay particles and about 25 per cent organic detritus.

\section{Observations}

\section{Macroorganisms}

The most abundant animal species in the cave over a 28 month period was Asellus recurvatus, a troglobite which inhabits all four pools. Phagocata subterranea was also abundant in the cave pools but only in Pool 4 a was this species found to exceed $A$. recurvatus in numbers of individuals. A few specimens of an earthworm, Eiseniella tetraedra (Savigny), were noted on each visit but this species appeared to be restricted in its distribution in the cave to water films associated with Pool 1. Several dense clusters of Tubifex tubifex (Müller) were observed in the mud substrate of Pools 1 and $4 \mathrm{a}$ in April, 1963. In February, 1964, colonies of T. tubifex were very numerous in both Pool 2 and Pool $4 \mathrm{a}$. 
Four or five specimens of the spring salamander, Gyrinophilus porphyriticus (Green), were found in Pool 2 in November, 1961; and in April, 1962, three adults, including one gravid female, were again noted in this pool. Only one specimen was observed there in August, 1962, and subsequent to that time no Gyrinophilus were seen in the cave.

An exact count of the number of isopods in Pool 1 was not made but population size was noted to decrease between November, 1961, and April, 1962. Subsequent to that time, however, their numbers appeared to remain about the same. The number of isopods in Pool 2 seemed to increase slightly from November, 1961, to August, 1962, and then remain constant through June, 1963, until a substantial decrease was noted in February, 1964. On the latter date a total count of the isopods in Pool 2 was made and population density was computed to be approximately $35.0 / \mathrm{m} .^{2}$. The decrease in numbers of animals between June, 1963, and February, 1964, could not be calculated because counting was not begun until the latter date.

Pool 3 was not discovered until April, 1963, and at this time only a few isopods were noted. By February, 1964, the number of isopods had increased appreciably and more than 30 animals were counted.

As in Pool 2, the total number of isopods in Pool 4 a decreased from June, 1963, to February, 1964. The population in Pool $4 \mathrm{~b}$ appeared to remain relatively constant, however. Total counts were made in both pools in February, 1964, and population densities were computed to be $25.0 / \mathrm{m}^{2}$ in Pool $4 \mathrm{a}$ and $60.9 / \mathrm{m}^{2}$ in Pool $4 \mathrm{~b}$.

A count of the isopods in Chadwell's Cave on March 1, 1964, indicated a population density of only $6.0 / \mathrm{m} .{ }^{2}$, substantially lower than in any of the Banners Corner Cave pools. The number of flatworms was less than the number of isopods and only about six worms were observed. The pool in Chadwell's Cave is slightly different than those in Banners Corner since it is fed by a slowly moving stream and has very little bottom sediment. As far as can be determined sewage does not enter this cave, and the amount of organic material in the pool is small in comparison with that in the Banners Corner Cave pools. In terms of the types and abundance of aquatic fauna, Chadwell's Cave approaches what could be termed a typical central Appalachian cave.

Flatworm populations appeared to fluctuate in size more than the isopod populations in Banners Corner Cave during the period of observation. It should be noted, however, that planarians frequently burrow into the mud substrate and an accurate estimate of population size is often impossible. 
The largest number of flatworms in Pool 1 was observed in November, 1961. By April, 1962, their numbers had decreased roughly in proportion to the decrease in number of isopods already noted for this pool. An estimated population size on this date was between 25 and 50 individuals. In June, 1963, only two specimens were observed, but in February, 1964, the number of worms had increased to the April, 1962, level.

In Pool 2 there was a marked decrease in the number of flatworms from November, 1961, to April, 1962, and in June, 1963, no flatworms were found in this pool. In February, 1964, however, the number of planarians had increased markedly and animals were in greater abundance than on any previous visit. The number of flatworms in Pool 2 on the latter visit was roughly equal to the number of isopods.

When Pool 3 was first discovered in April, 1963, it contained a relatively large number of planarians, but in June, 1963, no planarians, could be found, and in February, 1964, only a few individuals were noted. This decrease in the number of flatworms appeared to coincide with the increase in the number of isopods.

There was a slight increase in the number of flatworms in Pool $4 \mathrm{a}$ over the 28 month period, but in Pool $4 \mathrm{~b}$ the number of flatworms remained comparatively constant.

\section{Microorganisms}

The presence of coliform bacteria in Pools $2,4 \mathrm{a}$, and $4 \mathrm{~b}$ was confirmed at the end of a 24 hour incubation period. Tubes of nutrient broth ( $1 \%$ dextrose) were also inoculated with water from these three pools and within 24 hours of incubation samples from Pools 2 and $4 \mathrm{a}$ showed abundant bacterial growth. The inoculated tubes from Pool 4b showed only moderate growth at the end of 24 hours of incubation. No attempt was made to determine the types of or numbers of bacteria present in these cultures.

An abundance of coliform bacteria would be expected in water contaminated by human pollution such as that in Banners Corner Cave. Further, water rich in organic detritus and presumably in nitrogenous content would be expected to sustain the growth of a large number of different kinds of saprophytic bacteria.

Water from the stream pool in Chadwell's Cave was also positive for coliform bacteria, but this is interpreted as being the result of seepage from a nearby barnyard rather than from human sources. Bacterial growth on nutrient broth inoculated from this pool was moderate after 24 hours of incubation. Water in Chadwell's Cave is clear and shows no indication of sewage, and although the amount of 
bacteria actually present in the water is unknown it is probably no more than would be expected in any other sewage-free cave.

Table 1 is a list of microfauna identified from Pools 2 and $4 \mathrm{a}$ in Banners Corner Cave. The most abundant member of the microfauna was Paramecium micromultinucleatum Powers and Mitchell, specimens of which were very numerous in a one liter sample. Spirostomum ambiguum (?) Kahl was also numerous in the sample as well as an unidentified, free swimming rotifer belonging to the order Ploima. The remainder of the material listed in Table 1 was present in much less abundance. It is significant to compare the great diversity and abundance of microfauna in the contaminated pools of Banners Corner Cave with the relatively scarce microfauna in pools of comparable size in caves not affected by sewage influx. For example, water samples taken from "shrimp pools" in Mammoth Cave, Kentucky (T.C. Barr, Jr. and R.A. Kuehne, pers. comm.) were not nearly as well populated with microorganisms as the sample from Banners Corner Cave.

Table 1

List of the microfauna from a 1 liter sample of water from Pool 2 and Pool 4a, Banners Corner Cave, Russell County, Virginia. February 29, 1964

\begin{tabular}{lc}
\hline PROTOZOA & GASTROTRICHA-unidentified \\
Paramecium micromultinucleatum* & NEMATODA \\
Spirostomum ambiguum (?)* & Rhabditidae - 4 specimens (2 larvae) \\
Astacia sp. & OLIGOCHAETA \\
Ciliates - unidentified & Paranais sp. - 1 specimen \\
Flagellates - unidentified & Aeolosoma hemprichi-1 specimen \\
TREMATODA & ACARINA \\
1 egg & Hydrachnellae \\
ROTIFERA & \\
Ploima* &
\end{tabular}

* Very abundant in sample.

Physicochemical Analysis

Comparison of physicochemical data from Banners Corner Cave (Table 2) with that from Chadwell's Cave and Mammoth Cave (Table 3) indicates that $\mathrm{pH}$, total alkalinity, and temperature are similar in the three caves during the winter. 
The most significant values were obtained for chloride content and oxygen concentration. High chloride content values such as $9.0 \mathrm{mg}$./l. for Pool $4 \mathrm{a}$ and $14.0 \mathrm{mg}$./l. for Pool 2 are interpreted as further evidence for sewage contamination of these pools (see American Public Health Service, 1960). Pool 4b, relatively free of visible sewage, had the same chloride content (2.0 mg./l.) as the stream pool in Chadwell's Cave.

The small amount of dissolved oxygen in Pool 2 is believed to be a reflection of a high biochemical oxygen demand (BOD) and is not surprising in view of the large amount of organic material found in the water and on the bottom substrate. The depletion of free oxygen from polluted aquatic habitats by oxidation of organic wastes and through respiratory demands by microorganisms is well known.

In contrast to Pool 2, the amount of dissolved oxygen in Pool $4 \mathrm{~b}$ appears much higher and compares with the value obtained from the pool in Chadwell's Cave. Similarly, both of these values fall within the range recorded for a number of pools and streams in Mammoth Cave. Oxygen tension was not determined in Pool $4 \mathrm{a}$ but in view of its high degree of visible pollution, the value there would probably be comparable to the one obtained from Pool 2.

Table 2

Analysis of pool water, Banners Corner Cave, Russell County, Virginia February 29, 1964

\begin{tabular}{l|c|c|c|c|c}
\hline & $\begin{array}{c}\text { Chloride } \\
\text { mg./l. }\end{array}$ & $\begin{array}{c}\text { Oxygen } \\
\text { mg./l. }\end{array}$ & $\begin{array}{c}\text { Alkalinity } \\
\text { mg./l. }\end{array}$ & $\mathrm{pH}$ & $\begin{array}{c}\text { Water } \\
\text { Temperature }\end{array}$ \\
\hline Pool \# 2 & 14.0 & 2.8 & 145.0 & 7.4 & $9.5^{\circ} \mathrm{C}$ \\
Pool \# 4a & 9.0 & - & 168.0 & 7.2 & - \\
Pool \#4b & 2.0 & 9.2 & 130.0 & 7.8 & -
\end{tabular}

Table 3

Analysis of water, Chadwell's Cave, Claiborne County, Tennessee (stream pool, March 1, 1964) and Mammoth Cave, Edmonson County, Kentucky (range in values from three areas, November, 1961-November, 1962)

\begin{tabular}{|c|c|c|c|c|c|}
\hline & $\begin{array}{c}\text { Chloride } \\
\text { mg./l. }\end{array}$ & $\begin{array}{l}\text { Oxygen } \\
\text { mg./l. }\end{array}$ & \begin{tabular}{|c|}
$\begin{array}{c}\text { Alkalinity } \\
\text { mg./l. }\end{array}$ \\
\end{tabular} & pH & $\begin{array}{c}\text { Water } \\
\text { Temperature }\end{array}$ \\
\hline $\begin{array}{l}\text { Chadwell's Cave } \\
\text { Mammoth Cave* }\end{array}$ & 2.0 & $\begin{array}{c}10.0 \\
7.2-12.6\end{array}$ & $\begin{array}{c}104.0 \\
86.0-190.0\end{array}$ & $\begin{array}{c}7.8 \\
7.3-8.1\end{array}$ & $\begin{array}{c}8.9^{\circ} \mathrm{C} \\
8.6^{\circ} \mathrm{C}-14.6^{\circ} \mathrm{C}\end{array}$ \\
\hline
\end{tabular}

* Unpublished data from R. A. Kuehne (pers. comm.). 


\section{Discussion}

A number of interesting trophic relationships are indicated by the foregoing observations and data. The basic trophic input in the polluted cave pools is apparently in the form of sewage-associated, organic material which probably serves as the chief nutrient medium for the growth of an abundant bacterial flora. Larger microorganisms such as protozoans, rotifers, and gastrotrichs, probably feed on particulate organic matter as well as on the bacteria themselves. Moreover, bacterial decomposition products resulting from the metabolic breakdown of nitrogenous compounds undoubtedly contribute certain ingredients which are utilized by a number of the organisms living in the pools. Coliforms, although only accidental to the cave water, might also, when present in large numbers, supplement the food supply of larger organisms.

Since more observations have been made on the macroscopic aquatic forms in the cave their relationships and trophic responses are better known. Stephenson (1930) discussed the feeding habits of tubifex worms in sewage and indicated that these organisms derive nutrition from bacteria and dead organic matter. The association of Tubifex tubifex with waters very low in free oxygen was noted by Stephenson (1930) and more recently reviewed by Pennak (1953). In addition to the fact that tubifex worms are bacteria- and organic-detritus-feeders in the cave pools they might also in turn serve as food for P. subterranea. Hyman (1951) has pointed out that annelids as well as rotifers, copepods and other small metazoans are favorite planarian foods. It is unfortunate, however, that most of our available information on planarian food preferences has come from laboratory studies rather than from observations in the natural habitats of these animals. This is especially true of cavernicolous flatworms where even laboratory observations are almost wholly lacking. Hyman (1951) has also indicated that larger flatworms feed on isopods and earthworms, among other things, but if this situation occurs in the pools of Banners Corner Cave it has not yet been observed. Chase and Blair (1937) in a brief discussion of the ecology of Sorocelis americana Hyman, a dendrocoelid cave planarian of the western Ozark region, noted evidence of this species feeding on cave isopods in Bat Cave, Adair County, Oklahoma. Their evidence, however, appears to be rather fragmentary and Mohr and Dearolf (see Hyman, 1939), who visited this cave sometime later, were unable to make a substantiating observation. According to Hyman (1939), Mohr reported (in personal communication) "thousands" of $S$. americana on a bat guano deposit in the stream of Bat Cave but apparently could find no evidence that 
these flatworms were predaceous on the isopods that also occur in the stream. While it is true that planarians are frequently associated with isopods in cave pools (Holsinger, 1963a), both of these forms seem to "go their own way" in Banners' Corner Cave and neither of these species (with the possible exception of Pool 2) appears to occupy the same area of the given pool which they inhabit. This may involve substrate preference rather than mutual exclusion and will be discussed more thoroughly below.

On the basis of the limited available evidence, it appears more likely that cave planarians feed on fecal material and other organic detritus, rather than cave isopods. This opinion is further substantiated when one considers that perhaps the two largest populations of cave planarians yet recorded in North America (Banners Corner Cave, Va. and Bat Cave, Okla.) were in pools containing large deposits of fecal wastes. In Sauta Cave, Jackson County, Alabama, a large population of Sphalloplana alabamensis Hyman, approximately twothirds the size of the one in Pool 4 a of Banners Corner Cave, was observed in a rimstone pool where large amounts of decaying wood had accumulated. Whether flatworms actually feed on the organic particulate matter or are only predaceous on the smaller organisms such as protozoans, rotifers, etc. which also occur in pools where this material is present is debatable. One may speculate that cave flatworms are able to incorporate both types of food into their diet.

The feeding habits and food preference of aquatic cave isopods are little better known than those of cave planarians. Marshall and Orr (1960) indicated that isopods in general are omnivorous but apparently this reference was based mostly on the habits of marine species. Pennak (1953) in a discussion on the ecology of American fresh water isopods (Asellidae) referred to this group as scavengers, and Poulson (1964) stated that cave isopods eat only dead organic matter in nature although epigean forms may also eat live organic matter. Similarly, the writer (Holsinger, 1963 b) has noted asellid isopods feeding on frog and toad carcasses in several Appalachian caves. Most of the available evidence on the subject of food preferences and feeding habits of cave isopods appears to suggest that these animals are generally organic detritus feeders. The large amount of organic material in the pools of Banners Corner Cave could account for the abundant isopod fauna.

Lowered oxygen tension in Pool 2 and probably also in Pool 1 and $4 \mathrm{a}$ has a tendency to be a limiting factor in the distribution of isopods in these pools. In Pool 1, isopods, with very few exceptions, concentrate toward the end of the pool with the rock substrate and in the shallower water. They are usually as abundant in the nearby water- 
films as in the shallow end of the pool. Isopods were also found on the rocky bottomed portions of Pool 2 in the shallow areas near the edge, but in Pool $4 \mathrm{~b}$ these animals reach their greatest concentration toward the center of the pool where the substrate is composed largely of silt. Pool 4b, however, in contrast to pools 2 and $4 \mathrm{a}$ is relatively unpolluted and as previously mentioned it has an oxygen tension of $9.2 \mathrm{mg}$./l. (compared to only $2.8 \mathrm{mg}$./l. for Pool 2). The organic material on the bottom of Pool 4b, while present in large amounts, is essentially vegetable debris and not sewage. In Pool 3, also believed to be unpolluted, isopods are distributed at random over the bottom substrate, there being no apparent tendency for these animals to congregate in shallower areas. It is reasonable to assume that oxygen tensions are probably slightly higher in the water films and shallow areas of the polluted pools than in the deeper waters near their center. To what extent $A$. recurvatus can tolerate lowered oxygen tension is unknown, but the observed tendency on the part of this species to migrate to and aggregate in areas where dissolved oxygen concentrations are presumably higher appears to be significant. Additional data are needed, however, before any critical oxygen tension limits for isopod distribution in these pools can be established.

Distributional patterns of flatworms in the cave pools appear to be somewhat different than those noted for isopods. In Pool 1 and Pool $4 \mathrm{a}$ planarians exhibited a tendency to concentrate in deeper water near the center. In Pool 2, however, there was a greater aggregation of flatworms along the edges in shallow water than in the center. The preference of these animals for a mud substrate rich in organic residue might account for their distributional behavior in Pools 1 and $4 \mathrm{a}$, but it seems to have little bearing in Pool 2. Furthermore, what effect (if any) lowered oxygen tension has on the distribution of the flatworm populations must await additional and more critical observations.

The spring salamander, $G$. porphyriticus, did not appear to be abundant in the cave at any time but the fact that this species was observed to feed on $P$. subterrane $a^{4}$ ) indicates that, when present, it may exert considerable predation pressure on the flatworms. In addition, the carnivorous habits of this salamander make it at least a potential predator on A. recurvatus, but whether or not it actually feeds on this species in nature is not known.

\section{Conclusions}

1. Four pools were observed in Banners Corner Cave, Russell County, Virginia, over a 28 month period from November, 1961, to February,

4) Observation by J. E. Cooper on November 30, 1961. 
1964. Three of these pools were visibly polluted with septic tank effluent which seeps into the cave from the ground above, and at one time or another during the observational period all of these pools contained large populations of flatworms (Phagocata subterranea) and isopods (Asellus recurvatus).

2. Appreciable changes in the population densities of both isopods and flatworms were noted over the 28 month period but attempts to correlate these changes with either physical parameters or biotic factors were not made.

3. Physicochemical data from Pool 2 indicated that its chloride content was very high but that its oxygen tension was very low. Both of these values were interpreted as evidence of sewage pollution. The low oxygen content of this pool is believed to be a result of high BOD which is usually characteristic of pools polluted with organic sewage. Pool $4 \mathrm{~b}$, which appeared to be relatively unpolluted, had an oxygen tension and a chloride content comparable to those found in two caves presumably not affected by sewage effluent.

4. Microscopic examination of the water from Pool 2 and 4 a revealed a large amount of suspended organic material and a comparatively large microfauna, especially rich in protozoans and rotifers. Bacteriological analysis of the water from Pools 2, 4a, and $4 \mathrm{~b}$ indicated an abundance of coliforms and other bacteria (probably saprophytic) although the latter were less abundant in Pool $4 \mathrm{~b}$ where little evidence of pollution exists.

5. The influx and accumulation of sewage rich in organic matter is believed to be the basic trophic input in the contaminated pools of Banners Corner Cave. It is further suggested that this material serves as a rich food source for saprophytic bacteria as well as for much of the aquatic fauna, including both micro- and macroforms. Trophic relationships between the larger aquatic forms were discussed but few definitive conclusions can be reached at this time. Gyrinophilus porphyriticus, when present in the cave pools, may be predaceous on flatworms.

6. The unusual situation in Banners Corner Cave not only offers the opportunity to study the influence of sewage pollution on a freshwater habitat but, probably of even more importance, it offers an excellent chance to gain further insight into the little known trophic dynamics of the subterranean aquatic environment. 


\section{SUMMARY}

Four pools were observed in Banners Corner Cave, Russell County, Virginia, over a 28 month period from November, 1961, to February, 1964. Three of these pools were visibly polluted with sewage which had seeped into the cave from septic tanks located on the hill above. All four of these pools, at one time or another during the study, contained large populations of planarians, Phagocata subterranea Hyman and isopods, Asellus recurvatus Steeves.

Physicochemical and microbiological analyses of the pool waters indicated that oxygen tension is a low as $2.8 \mathrm{mg}$./l. in one pool and that coliforms and other forms of bacteria (probably saprophytic) are abundant in the contaminated waters of the cave. Microscopic examination of the pool waters revealed a rich and varied microfauna, especially protozoans and rotifers. In addition, the polluted pools contained large amounts of colloidal materials which are believed to be rich in organic content.

The influx and accumulation of sewage rich in organic matter is believed to be the basic trophic input in the contaminated pools. It is suggested that this material serves as an important food source for saprophytic bacteria as well as for much of the aquatic fauna, including both micro- and macroforms. Precise trophic relationships between the larger aquatic organisms have not been worked out but several significant feeding responses have been observed.

\section{RÉSUMÉ}

Quatre mares situées dans la Banners Corner Cave, Russell County, Virginie, ont fait l'objet d'observations réparties sur une période de 28 mois, de novembre 1961 à février 1964.

Trois de ces mares étaient visiblement polluées par les eaux-vannes qui se sont infiltrées dans la grotte à partir des fosses septiques situées sur la colline où est creusée cette cavité. A un moment ou à un autre de la période d'observation ces quatre mares abritaient d'importantes populations de Planaires (Phagocata subterranea Hyman) et d'Isopodes (Asellus recurvatus Steeves).

Les analyses microbiologiques et physiochimiques des eaux ont donné dans une mare une tension d'oxygène aussi faible que $2,8 \mathrm{mg} / \mathrm{l}$ et montré que dans les eaux polluées de la grotte les bactéries coliformes et autres (vraisemblablement saprophytiques) sont abondantes. L'examen microscopique de l'eau des mares révèle une riche microfaune variée, surtout en Protozoaires et Rotifères. En outre, les mares polluées renferment de grandes quantités de substances colloïdales qui seraient riches en matières organiques.

L'influx et l'accumulation des eaux-vannes, riches en matières organiques, sont, croyons-nous, l'apport trophique de base des mares contaminées.

Nous suggérons que ces eaux sont une importante source de nourriture aussi bien pour les bactéries saprophytiques que pour la plus grande partie de la faune aquatique (micro- et macroformes). Les relations trophiques précises entre les organismes aquatiques de plus grande taille n'ont pas été déterminées mais nous avons observé plusieurs réponses alimentaires significatives. 


\section{REFERENCES}

American Public Health Association (1960) - Standard methods for the examination of water and wastewater. New York, 11th Ed., 626 p.

Chase, H. D., and Blair, A. P. (1937) - Two blind isopods from northeastern Oklahoma. Am. Midl. Nat., 18: 220-224.

Holsinger, John R. (1963a) - Studies on the ecology and geographic distribution of macroscopic cavernicolous invertebrates of the central Appalachians. Masters Thesis, Madison College, Harrisonburg, Virginia.

- (1963b) - Annotated checklist of the macroscopic troglobites of Virginia with notes on their geographic distribution. Bull. Nat. Speleol. Soc., 25 : $23-36$.

Husson, Roger (1962) - Les ressources alimentaires des animaux cavernicoles. Cahiers D'Etudes Biol. (Lyon), No. 8-9: 103-116.

Hyman, L. H. (1939) - North American triclad Turbellaria. X. Additional species of cave planarians. Trans. Am. Micro. Soc., 58: 276-284.

- (1951) - The invertebrates: Platyhelminthes and Rhynchocoela (Vol. II). McGraw-Hill Book Company, Inc., 550 p.

Marshall, S. M., and Orr, A. P. (1960) - Feeding and nutrition: in H. Waterman, The physiology of the Crustacea (Vol. I). Acad. Press, New York, p. 227-258.

Pennak, Robert W. (1953) - Fresh-water invertebrates of the United States. Ronald Press Company, New York, 769 p.

Poulson, Thomas L. (1964) - Animals in aquatic environments: animals in caves: in The handbook of physiology - Adaptation to the environment (Sec. 4). Am. Physiol. Soc., Washington, D. C., p. 749-771.

Stephenson, J. (1930) - The Oligochaeta. Oxford Press, London, 978 p. 